\title{
Communication
}

\author{
[Comunicação]
}

\section{Lactation stage and udder health status of Santa Ines ewes}

\author{
[Estágio da lactação e saúde da glândula mamária em ovelhas da raça Santa Inês]
}

\author{
M.G. Blagitz, N.R. Benites, P.A. Melville, C.F. Batista, P.S. Betiol, M.R. Azedo, \\ V. Gomes, F.N. Souza, A.M.M.P. Della Libera*
}

Faculdade de Medicina Veterinária e Zootecnia - USP - São Paulo, SP

\begin{abstract}
Mastitis is an important disease of sheep with serious economic losses, even in meat-producing sheep (Clements et al., 2003; Moroni et al., 2007). It is well known that the composition of ewe milk undergoes marked changes throughout the lactation (Cuccuru et al., 1997; Bergonier et al., 2003; Sevi et al., 2004). These changes during the lactation may trigger periods of increased or decreased susceptibility to mastitis, or may even turn out qualitative changes in milk (Cuccuru et al., 1997; Bergonier et al., 2003). Differences among breeds were also reported. Indeed, the majority of the information available for sheep is concerned predominantly with dairy sheep in Mediterranean countries. So, there are few data non-dairy sheep breeds (Conington et al., 2008).
\end{abstract}

Thus, the purpose of the present study was to make an inference about the risk of infection and inflammation regarding the phase of lactation of Santa Ines ewes.

The lactation period of 33 recently lambed Santa Ines ewes from extensive and semi-intensive management systems was followed. Sheep were submitted to physical examination of their udders (Baumgartner, 2005), strip cup test, California Mastitis test (CMT) and collection of milk samples for bacteriological and somatic cell count (SCC). Throughout lactation period of the assessed ewes, samples were grouped, according to days after parturition in: stage 1 - ewes from the $3^{\text {rd }}$ to the $30^{\text {th }}$ day postpartum; stage $2-$ from the $31^{\text {st }}$ to the $60^{\text {th }}$ day postpartum; stage $3-$ from the $61^{\text {st }}$ to the $90^{\text {th }}$ day postpartum; and stage $4-$ from the $91^{\text {st }}$ to the $120^{\text {th }}$ day postpartum.

The first strip was discarded, and then the milk samples for bacteriology investigation were aseptically collected. Milk samples were streaked onto a 5\% sheep-blood agar. The plates were aerobically incubated at $37^{\circ} \mathrm{C}$ and examined at 24 and $48 \mathrm{~h}$. Positive samples were submitted to biochemical analyses for the identification of the bacteria (Oliver et al., 2004).

The direct microscopic SCC (DMSCC) and differential leukocytes count were performed in duplicate using hematoxylin-eosin. The purpose of the search was to reach a total count from 100 microscopic fields, which the leukocytes were differentiated in mononuclear and polymorphonuclear. The working factor was 3,751 in all cases. Samples analyzed by automatic SCC (Bentley Instruments, Chaska, $\mathrm{MN}, 55318$, USA) were collected in flasks containing bronopol and sent to the Milk Quality Laboratory at the Escola Superior de Agricultura Luiz de Queiroz, ESALQ-USP.

Samples collected for the strip cup test and bacteriological examination were ranked by scores, so that negative samples scored 0 and positive samples scored 1. CMT results were graded in: 1) no precipitate; 2) trace precipitate; 3) distinct precipitate/weak gel formation; 4) distinct gel formation; 5) strong gel formation (Clements et al., 2003). During the study, some animals were sold by the owners and others died. 
To determine differences between old and new infections, the Cochran Test and the Qui-Square Test were used. The Cochran Test was useful to evaluate the missing teats. During this study, it was considered a new infection, every time a new bacterium was identified. To compare tests used during this study, ANOVA, Friedman test and pearson correlation coefficient test, were applied.
Most of the milk samples collected were negative ( $80.2 \%$ of all samples). Among positive samples, most of the isolates were Staphylococcus spp. (94.3\%) (Table 1), which are the main etiological agents of intramammary infections (IMI) in small ruminants (Bergonier et al., 2003; Moroni et al., 2007).

Table 1. Frequency of bacterial genera and species isolated from milk samples collected from 33 Santa Ines ewes throughout lactation period

\begin{tabular}{|c|c|c|c|c|c|}
\hline & Stage 1 & Stage 2 & Stage 3 & Stage 4 & $\begin{array}{c}\text { Amount of } 4 \\
\text { stages }\end{array}$ \\
\hline Negative samples & $45(80.4 \%)$ & $49(79.0 \%)$ & $32(76.2 \%)$ & $16(80.0 \%)$ & $142(80.2 \%)$ \\
\hline Positive samples & $11(19.6 \%)$ & $11(21.0 \%)$ & $9(23.8 \%)$ & $4(20.0 \%)$ & $35(19.8 \%)$ \\
\hline Amount of samples & 56 & 60 & 41 & 20 & 177 \\
\hline$P$ value & \multicolumn{4}{|c|}{$\mathrm{P}=0.98$} & \\
\hline Isolated bacteria & & & & & \\
\hline Staphylococcus spp. & $6(10.7 \%)$ & $3(4.8 \%)$ & $4(9.5 \%)$ & $0(0.0 \%)$ & $13(7.3 \%)$ \\
\hline Staph. kloosii & $4(7.1 \%)$ & $2(3.2 \%)$ & $2(4.8 \%)$ & $0(0.0 \%)$ & $8(4.5 \%)$ \\
\hline Staph. hyicus & $0(0.0 \%)$ & $2(3.2 \%)$ & $2(4.8 \%)$ & $2(10.0 \%)$ & $6(3.4 \%)$ \\
\hline Staph. haemolyticus & $0(0.0 \%)$ & $1(1.6 \%)$ & $1(2.4 \%)$ & $1(5.0 \%)$ & $3(1.7 \%)$ \\
\hline Staph. camosus & $1(1.8 \%)$ & $0(0.0 \%)$ & $0(0.0 \%)$ & $0(0.0 \%)$ & $1(0.6 \%)$ \\
\hline Staph. chromogenes & $0(0.0 \%)$ & $1(1.6 \%)$ & $0(0.0 \%)$ & $0(0.0 \%)$ & $1(0.6 \%)$ \\
\hline Staph. warneri & $0(0.0 \%)$ & $0(0.0 \%)$ & $0(0.0 \%)$ & $1(5.0 \%)$ & $1(0.6 \%)$ \\
\hline Streptococcus dysgalactiae & $0(0.0 \%)$ & $1(1.6 \%)$ & $0(0.0 \%)$ & $0(0.0 \%)$ & $1(0.6 \%)$ \\
\hline Streptococcus uberis & $0(0.0 \%)$ & $1(1.6 \%)$ & $0(0.0 \%)$ & $0(0.0 \%)$ & $1(0.6 \%)$ \\
\hline
\end{tabular}

No differences were found in the results of bacteriological analyses in relation to the stage of lactation $(\mathrm{P}=0.98)$ and regarding new infection $(\mathrm{P}=0.49$; results not showed $)$. This is in agreement with others who described that the prevalence of subclinical IMI throughout lactation period remained relatively constant (AlMajali and Jawabreh, 2003; Bergonier et al., 2003). Indeed, the persistence of subclinical IMI during lactation is often high due to the poor detection and elimination of such infections during lactation, and to their frequent staphylococcal origin (Bergonier et al., 2003; Blagitz et al., 2008). Conversely, some authors observed that dairy sheep were more susceptible to infections in the beginning of lactation (Bergonier et al., 2003), or both in the end and in the beginning of lactation (Menzies and Ramanoon, 2001).

Physical examination of the udder of most ewes did not show any clinical changes (results not showed). No significant difference was found in CMT $(\mathrm{P}=0.90)$ and DMSCC by polymorphonuclear cells count $(\mathrm{P}=0.52)$, mononuclear cells count $(\mathrm{P}=0.14)$ and total cells count $(\mathrm{P}=0.17)$ throughout lactation (Table 2). Nevertheless, a tendency toward an increase in automatic SCC during the last stage was observed $(\mathrm{P}=0.051)$ (Table 2). Further studies also showed increased cell counts in the end of lactation that may be related to a greater resistance to infection in this period (Cuccuru et al., 1997; Bergonier et al., 2003; Blagitz et al., 2008).

The presence of bacteria did not change the proportion of polymorphonuclear and mononuclear cells throughout lactation, as seen in DMSCC. Thus, the variation of SCC observed in these stages may have been due to physiological reasons. 
Table 2. Average, standard variation (SV), median, and range values (cells $/ \mathrm{mL}$ ) of automatic somatic cell count (SCC) and direct microscopic SCC (DMSCC), and California Mastitis Test CMT) results obtained from milk samples collected from 33 Santa Ines ewes throughout lactation period

\begin{tabular}{|c|c|c|c|c|}
\hline Automatic SCC & Stage 1 & Stage 2 & Stage 3 & Stage 4 \\
\hline Average & $864,491.1$ & $727,525.4$ & $1,458,964.3$ & $3,125,016.7$ \\
\hline SV & $1,618,484$ & $1,440,557.9$ & $4,303,187.8$ & $4,522,255.4$ \\
\hline Median & 217,000 & 208,000 & 282,000 & 754,000 \\
\hline Range & $8,000-, 062,000$ & $12,000-7,359,000$ & $5,000-27,600,000$ & $155,000-12,978,000$ \\
\hline Amount of samples & 56 & 59 & 42 & 18 \\
\hline$P$ value & & & $P=0.051$ & \\
\hline \multicolumn{5}{|l|}{$\begin{array}{l}\text { Polymorphonuclear } \\
\text { cells }\end{array}$} \\
\hline Average & 349,129 & $205,771.6$ & $84,343.6$ & 123,021 \\
\hline SV & $1,158,004.3$ & $822,255.9$ & $165,243.8$ & $207,109.8$ \\
\hline Median & 10,713 & 10,713 & 17,855 & 57,136 \\
\hline Range & $0-7,820,490$ & $0-6,274,247$ & $0-1,007,022$ & $3,571-928,460$ \\
\hline Amount of samples & 56 & 61 & 42 & 20 \\
\hline$P$ value & & & $\mathrm{P}=0.52$ & \\
\hline \multicolumn{5}{|l|}{ Mononuclear cells } \\
\hline Average & 141,182 & 43,496 & $52,884.8$ & $89,632.1$ \\
\hline SV & $351,161.7$ & $92,321.6$ & $125,830.1$ & $113,049.1$ \\
\hline Median & 10,713 & 7,142 & 10,713 & 35,710 \\
\hline Range & $0-1,892,630$ & $0-467,801$ & $0-789,191$ & $0-367,813$ \\
\hline Amount of samples & 56 & 61 & 42 & 20 \\
\hline$P$ value & & & $P=0.14$ & \\
\hline \multicolumn{5}{|l|}{ Total cells (DMSCC) } \\
\hline Average & $490,311.1$ & $249,267.5$ & $137,228.4$ & $212,653.1$ \\
\hline SV & $1,384,944.4$ & $89,409.6$ & 287,871 & 283,994 \\
\hline Median & 24,997 & 17,855 & $26,782.5$ & 114,272 \\
\hline Range & $3,571-8,641,820$ & $3,571-6,742,048$ & $3,571-1,796,213$ & $3,571-1,171,288$ \\
\hline Amount of samples & 56 & 61 & 42 & 20 \\
\hline$P$ value & & & $P=0.17$ & \\
\hline \multicolumn{5}{|l|}{ CMT } \\
\hline Negative (grade 1) & $36(64.3 \%)$ & $40(65.6 \%)$ & $22(52.4 \%)$ & $9(45.0 \%)$ \\
\hline Positive samples & $20(35.7 \%)$ & $21(34.4 \%)$ & $20(47.6 \%)$ & $11(55.0 \%)$ \\
\hline Samples graded 2 & $0(0.0 \%)$ & $0(0.0 \%)$ & $0(0.0 \%)$ & $0(0.0 \%)$ \\
\hline Samples graded 3 & $12(21.4 \%)$ & $15(24.6 \%)$ & $13(31.0 \%)$ & $4(20.0 \%)$ \\
\hline Samples graded 4 & $8(14.3 \%)$ & $5(8.2 \%)$ & $5(11.9 \%)$ & $5(25.0 \%)$ \\
\hline Samples graded 5 & $0(0.0 \%)$ & $1(1.6 \%)$ & $2(4.8 \%)$ & $2(10.0 \%)$ \\
\hline Amount of samples & 56 & 61 & 42 & 20 \\
\hline$P$ value & & & $P=0.90$ & \\
\hline
\end{tabular}

In conclusion, no differences were observed in the bacteriological examination in any stage of lactation which point out a higher persistence of IMI in these animals. Furthermore, no significance differences in CMT, automatic and microscopic SCC were found during the lactation period, however, a tendency toward a higher SCC was encountered in the last stage.

Keywords: ewe, somatic cell count, lactation stage, mastitis 


\section{RESUMO}

Avaliou-se o risco de infecção em diferentes fases da lactação em 33 ovelhas da raça Santa Inês. Inicialmente a glândula foi submetida ao exame físico e à prova de fundo escuro. Posteriormente, amostras de leite foram coletadas assepticamente para a realização de exame bacteriológico - California Mastitis teste -, e contagens microscópica e automática de células somáticas. Nenhuma diferença foi observada entre as distintas fases de lactação. Observou-se alta persistência de infecções intramamárias, e tendência a maior contagem de células somáticas no último período de lactação, que pode ser oriunda da maior resistência a infecções neste período.

Palavras-chave: ovelha, contagem de células somáticas, fase da lactação, mastite

\section{ACKNOWLEDGEMENTS}

The authors would like to thank to FAPESP (proc. n. 2003/08582-7) for financial support.

\section{REFERENCES}

AL-MAJALI, A.M.; JAWABREH, S. Period prevalence and etiology of subclinical mastitis in Awassi sheep in southern Jordan. Small Rum. Res., v.47, p.243-248, 2003.

BAUMGARTNER, W. Clinical propedeutic of the internal diseases and skin diseases of the domestic animals. 6.ed. Berlin-Wien: Parey, 2005. $382 \mathrm{p}$.

BERGONIER, D.; CRÉMOUX, R.; RUPP, R. et al. Mastitis of dairy small ruminants, Vet. Res., v.34, p.689-716, 2003.

BLAGITZ, M.G.; BATISTA, C.F.; SOUZA, F.N. et al. Perfil celular e microbiológico do leite de ovelhas Santa Inês no período lactante e pósdesmame. Pesq. Vet. Bras., v.28, p.417-422, 2008.

CLEMENTS, A.C.A.; TAYLOR, D.J.; FITZPATRICK, J.L. Evaluation of diagnostic procedures for subclinical mastitis in meatproducing sheep. J. Dairy Res., v.70, p.139-148, 2003.
CONINGTON, J.; CAO, G.; STOTT, A. et al. Breeding for resistance to mastitis in United Kingdom sheep, a review and economic appraisal. Vet. Rec., v.162, p.369-376, 2008.

CUCCURU, C.; MORONI, P.; ZECCONI, A. et al. Milk differential cell counts in relation to total counts in Sardinian ewes. Small Ruminant Res., v.25, p.169-173, 1997.

MENZIES, P.I.; RAMANOON, S.Z. Mastitis of sheep and goats. Vet. Clin. N. Am.: Food Anim. Pract., v.17, p.333-355, 2001.

MORONI, P.; PISONI, G.; VARISCO, G. et al. Effect of intramammary infection in Bergamasca meat sheep on milk parameters and lamb growth. J. Dairy Res., v.74, p.340-344, 2007.

OLIVER, S.P.; LEWIS, M.J.; GILLESPIE, B.E. et al. Microbiological Procedures for the Diagnosis of Bovine Udder Infection and Determination of Milk Quality. 4.ed. Verona: National Mastitis Council, 2004. 47p.

SEVI, A.; ALBENZIO, M.; MARINO, R. et al. Effects of lambing season on stage of lactation on ewe milk quality. Small Rum. Res., v.51, p.251-259, 2004. 